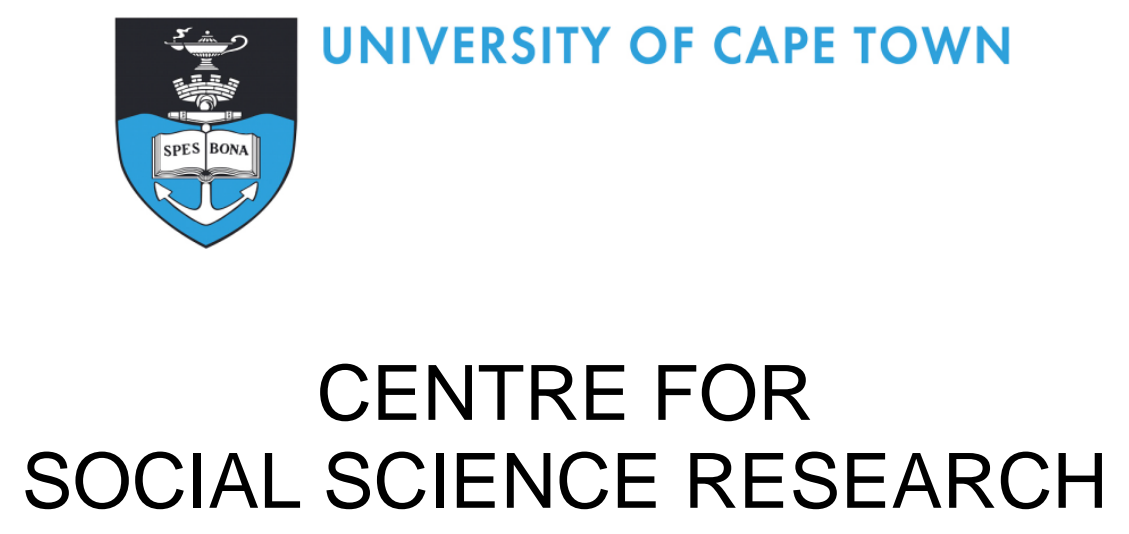

\title{
Donor agenda-setting, bureaucratic advocacy and cash transfers in Uganda (2002-2013)
}

Eduard Grebe

CSSR Working Paper No. 352

Legislating and Implementing Welfare Policy Reforms

December 2014
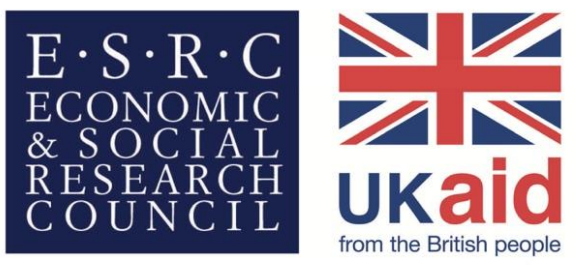

Research jointly supported by the ESRC and DFID

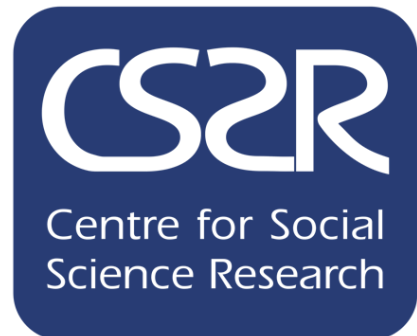


Published by the Centre for Social Science Research

University of Cape Town

2014

http://www.cssr.uct.ac.za

This Working Paper can be downloaded from:

http://cssr.uct.ac.za/pub/wp/352/

ISBN: 978-1-77011-339-8

(C) Centre for Social Science Research, UCT, 2014

(c) Creative Commons Attribution 4.0 International

(C.C. by 4.0) licence: https://creativecommons.org/licenses/by/4.0/

\begin{abstract}
About the author:
Eduard Grebe is based in the Centre for Social Science Research at the University of Cape Town. eduard.grebe@uct.ac.za.
\end{abstract}

Acknowledgements:

This paper is partly based on two previous conference papers on agenda-setting on cash transfers in Uganda. The author would like to acknowledge the contribution of

Prof Jeremy Seekings, who helped conceptualise the paper and provided tremendously useful comments on various drafts. We are grateful for funding for the LIWPR research programme from the UK Department for International Development, through the Economic and Social Research Council, through their Joint Fund for Poverty Alleviation. 


\section{Donor agenda-setting, bureaucratic advocacy and cash transfers in Uganda (2002-2013)}

\section{Abstract}

This paper focuses on donors and-in particular-bureaucrats as agents of change in welfare policy reform processes in Uganda between 2002 and 2013. It shows how donors managed to establish cash transfers on the development policy agenda (but failed to gain sufficient political support for implementation), and 'recruit' a group of supportive social development bureaucrats in the Ministry of Gender, Labour and Social Protection after 2002. From 2006, domestic political support increased markedly, in no small part owing to both continued donor support and bureaucratic advocacy. Bureaucrats increasingly became the frontline advocates of policy reform - acting both as the agents of a donor agenda and, increasingly, an autonomous constituency strongly supportive of cash transfers within the Ugandan state. This bureaucratic buyin' was an essential contributor to the increasing prominence of cash transfers in policy debates and in securing political support for the eventual implementation of a cash transfer pilot scheme from 2010. These bureaucrats actively lobbied other sections of the bureaucracy and members of the political elite. The paper contends that they-with donor support-succeeded in constructing a coalition in support of cash transfers, comprising sections of the bureaucracy (including some finance and planning technocrats), civil society organisations and political leaders in both the legislature and executive. This coalition enjoyed sufficient influence to secure the approval and successful implementation of a cash transfer pilot, as well as to firmly establish a national tax-funded social pension on the domestic political agenda by 2013.

\section{Introduction}

This paper addresses the role of donors and bureaucrats as agents of change in welfare policy reform processes in Uganda since 2002. While some attention had been paid to 'social safety nets' in national development planning during the 1990s, cash transfers only truly entered the policy agenda after 2002. From the early 2000s, donors - principally DFID - actively promoted cash transfers and increasingly focused on securing political support, but faced stiff resistance from 
conservative financial technocrats and a sceptical political elite. One important mechanism employed to promote cash transfers was to 'recruit' supportive social development bureaucrats as advocates of social protection policy reform within the Ugandan bureaucracy and political elite. This paper contends that the role of these bureaucrats was critical in overcoming resistance to 'hand-outs' and concerns that social protection programmes would be unaffordable and unsustainable.

From 2006, cash transfers were increasingly seen as an essential part of Uganda's development agenda, and by 2010, political support appeared to have increased very significantly (to the point where senior politicians were expressing support and social protection received substantial attention in the 2010 National Development Plan). Civil society organisations also vigorously promoted increased social protection between 2002 and 2010 (and beyond). In 2010, implementation of a donor-funded cash pilot scheme transfer started, and by late 2013, national rollout of a social pension was being seriously debated. This year may therefore constitute a turning point in that it may be the point at which sufficient political support for the implementation of a domesticallyfunded large-scale cash transfer was reached. This is addressed in the postscript to this paper. While some general studies on welfare policy-making in Uganda have been published (e.g. Hickey, 2003; Grant, 2006; Hickey et al., 2009; Golooba-Mutebi and Hickey, 2010), these have tended to focus on donors as agents of policy reform and the role of bureaucrats have been neglected. This paper addresses this gap in the literature by showing how donors and a portion of the Ugandan bureaucracy have acted in concert to promote reform, with substantial success.

Despite a generally pro-poor approach to development (reflected in investments in human capital development), the prevailing paradigm within the Ugandan state emphasised economic growth and productive activities and there existed strong resistance to cash transfers, especially from financial technocrats and the political elite. This was especially the case especially prior to 2006, but resistance continued up to and including 2013. From 2006, social development bureaucrats became increasingly strong advocates of cash transfers and social protection more broadly - and were more successful at securing support than donors had been between 2002 and 2006. An initial cash transfer pilot proposal (supported by donors and then-weak bureaucrats in the relevant department, the Ministry of Gender, Labour and Social Development) was blocked by the Minister of Finance in 2007. It took nearly a decade from the beginning of the first serious donor agenda-setting exercises - starting in 2002 - before the social protection agenda started to be translated into real policy commitments and a cash transfer pilot scheme (known as the Social Assistance Grants for Empowerment or SAGE) was initiated in 2010. 
As noted above, this paper's central contention is that domestic bureaucratic 'buy-in' was an essential contributor to the increasing centrality of cash transfers in the Ugandan development agenda and in securing political support for the eventual implementation of a substantial cash transfer pilot scheme. The approval and relatively successful implementation of the SAGE pilot from 2010, and the fact that a national tax-funded non-contributory pension was firmly on the political agenda by 2013 , reflected not only donor influence (donors were notably unsuccessful up to 2006), but also the success of social development bureaucrats in constructing a supportive coalition comprising sections of the bureaucracy (including some finance and planning technocrats), civil society organisations and political leaders in the legislature and executive. However, given the centralised, authoritarian and personalised character of the Museveni/NRM regime, the support of the President and his inner circle remained an unknown with significant implications for political commitment to cash transfers. ${ }^{1}$ Despite the slow take-up of cash transfers in Uganda, and substantial resistance encountered, the Ugandan case nevertheless stands in stark contrast to certain other African countries where donors (most prominently DFID) promoted similar schemes, e.g. Zambia, where domestic political actors never 'bought into' major reform (see Kabandula and Seekings, forthcoming). ${ }^{2}$

To clarify the periodisation: Three important periods in welfare policy reform can be identified, dominated by different actors: (1) failed donor agenda-setting on cash transfers prior to 2002 (see Grebe and Mubiru, 2014); (2) more astute donor agenda-setting of cash transfers with (weak) bureaucratic support and technocratic resistance (2002-2006); and (3) successful donor and bureaucratic

\footnotetext{
${ }^{1}$ It is important to note the dominance of the policy arena by a small and relatively insular elite - with Museveni himself at the pinnacle - in what Golooba-Mutebi and Hickey (2013) characterise as a 'dominant leader form of political settlement'. Museveni has governed in a highly personalised style (Mwenda, 2007; Tripp, 2010), and the National Resistance Movement (NRM) has dominated the legislature even after the re-introduction of multiparty elections in 2006.

${ }^{2}$ This paper forms part of a series on the politics of social protection in Uganda. While the focus here is on the role of donors and bureaucrats in the politics of planning, building political support for, financing, implementing and scaling up cash transfer programmes, the broader evolution of Ugandan development policy under the Museveni/NRM regime, the 'pre-history' of cash transfers and the linkages between the 'poverty eradication era' of the 1990s and the increase in prominence of social protection (in general) and cash transfers (in particular) are reviewed in greater detail in Grebe and Mubiru (2014). This paper therefore focuses largely on the post-2002 period and should ideally be read with the history and broader context sketched out in the related paper referred to above. Both these papers on Uganda form part of a broader research project on the politics of welfare policy reform in Africa, and it is anticipated that in later phases of the research a more comparative focus will be adopted. Important questions like how and why Uganda differed or were similar to other African countries, like Kenya and Zambia, reforming their welfare regimes are therefore not addressed in any detail at this stage. This is however, and important area of on-going research.
} 
advocacy on cash transfers culminating in implementation of a cash transfer pilot (2006-2013) and consideration of a national social pension from 2013 onwards. Bureaucrats became unequivocally central to advocacy efforts from 2010 onwards. The second two periods are covered in detail in this paper. It is possible that a fourth period - one of national scale-up — was on the horizon, and late 2013/early 2014 appeared to be a crucial moment, but at the time of writing ${ }^{3}$ this can only be speculated about (see postscript).

By early 2014, the donor-funded SAGE cash transfer pilot scheme, which forms part of the broader Expanding Social Protection (ESP) programme, remained the only significant cash transfers scheme in Uganda. In 2010, the Government of Uganda began to implement the SAGE cash transfer pilot in fourteen districts (with a fifteenth added in 2013). ${ }^{4}$ It comprised a social pension available to all persons of 65 years and older (except in the relatively poorer Karamoja region, where the age of eligibility was 60) and a poverty-targeted grant aimed at the most vulnerable $15 \%$ of families in each pilot district. Both SAGE and the broader ESP were largely donor-funded-primarily by the United Kingdom's Department for International Development (DFID) and the Irish bilateral aid agency IrishAid, with technical assistance from UNICEF-but were being implemented by the Ugandan government through a dedicated secretariat in the Ministry of Gender, Labour and Social Development (MGLSD). This new Social Protection Secretariat was well-capacitated-especially compared to the historically weak MGLSD - and received substantial technical and financial assistance from donors, including in the form of embedded staff with key roles (deployed by an agency contracted to donors).

That the pilot formed part of a broader policy-development and social protection promotion programme (the ESP, which had as its core goal the "embedding of a national social protection system') reflected (1) the hostile political environment donors initially encountered and (2) a realisation that domestic politics was the key determinant of success (see Hickey et al., 2009). Substantial resistance (from a sceptical political elite and fiscally conservative technocrats) to social assistance, and cash transfers in particular, had to be overcome. This is why agenda-setting and political support-building by donors and social development bureaucrats were so central to welfare policy reform in Uganda. More detail on the general political environment and the evolution of the prevailing

\footnotetext{
${ }^{3}$ Fieldwork (largely consisting of key informant interviews) for this research was conducted during early 2014 and the paper was being finalised in late 2014. Further fieldwork is envisaged, both with a view to addressing other aspects of the politics of social protection in Uganda and to address areas where insufficient data is available for optimal analysis at this stage.

${ }^{4}$ The first payments to beneficiaries were only made in 2011, so 2011 is sometimes referred to as the year in which the SAGE pilot was initiated.
} 
developmental paradigm in Uganda since 1986 can be found in Grebe and Mubiru (2014).

\subsection{Outline}

The rest of this introduction provides a very brief background to the slow appearance of cash transfers on the development agenda in Uganda. The paper then turns to the early agenda-setting efforts of donors, including through the establishment of a donor-supported Social Protection Task Force in the MGLSD and the failure of an SPTF-proposed cash transfer pilot ${ }^{5}$ to attain Finance Ministry approval (2002-2006). By 2006, cash transfers featured more prominently on the policy agenda, but this did not translate into sufficient political support for programme implementation to be initiated. Donors and supportive bureaucrats intensified their agenda-setting and advocacy efforts, culminating in the acceptance of the ESP/SAGE proposal in 2010. After 2010, bureaucrats played an increasingly important role in the promotion of social protection and cash transfers, including through donor-funded investment in and support for a 'civil society platform' and 'parliamentary forum' on social protection, as well as substantial intra-governmental lobbying by social development bureaucrats (primarily those in the MGLSD and the newly-created Social Protection Secretariat it housed). Part of this process was the generation of evidence on the impacts of cash transfers through the SAGE pilot, which was coupled with an explicit data collection, operational and impact research, evidence dissemination, as well as awareness and support-building strategy. It concludes that the activities of both donors and social development bureaucrats were crucial in securing sufficient political support for a cash transfer to be launched and implemented successfully - and that these activities in turn were predicated upon the recognition that welfare policy reform depended on politics and not simply on formal policy-making or the availability of resources.

In a postscript, the paper (somewhat tentatively) addresses the more recent political debates around national scale-up of a social pension, in which social development bureaucrats continued to play a central role and finance and planning technocrats became increasingly involved in planning for a proposed national rollout of social pensions. However, the commitment of the President and other high-level political leaders to the scale-up proposal remained unclear in early 2014. As noted above, late 2013/early 2014 may turn out to be a critical

\footnotetext{
${ }^{5}$ In the light of DFID's strong influence in the SPTF (see Grant, 2006), and the fact that the pilot would have been fully donor-funded, this proposed cash transfer pilot may perhaps be better described as a donor proposal.
} 
turning point at which cash transfers truly attained sufficient momentum to support sustainable resourcing and implementation from domestic resources.

\subsection{Background: development policy in Uganda prior to cash transfers gaining in prominence (1986- 2002)}

Uganda is a low-income country (GNI per capita US\$480'), but made significant developmental strides during the 1990s and 2000s. In particular it sustained relatively high levels of economic growth ${ }^{7}$ and the proportion of the population living in poverty halved between 1992 and 2010, although inequality increased. ${ }^{8}$ The Museveni government gained a reputation for good governance, low levels of corruption and good management of the economy, consequently attracting high levels of foreign aid. Its policies have been widely described as pro-poor (Melo et al., 2012; Mosley, 2012). It invested substantial resources in social services like health and education (Hickey, 2012), introducing universal primary education in 1997 (Nishimura et al., 2008) and abolishing user fees for health in 2001, with a marked increase in utilisation (Nambyonga et al., 2005). Unfortunately, increased public expenditure did not necessarily result in commensurate improvements in service delivery (Reinikka, 2001), the quality of education may have declined as enrolments increased (Deininger, 2003; Robichaud et al., 2014), education budgets stagnated in recent years (Robichaud et al., 2014) and out-of-pocket expenditures on health remained high (Orem et al., 2011).

Despite investment in human capital development, welfare policy had been limited in scope and social protection largely limited to social security for formal sector employees (public sector pensions and the National Social Security Fund for private sector employees). For most of the post-colonial period, Uganda's developmental trajectory was largely a continuation of the approach of late colonial British policy, described by Seekings (2013) as 'developing' African economies through 'rather ineffective "developmental

\footnotetext{
${ }^{6}$ GNI per capita (Atlas method) for 2012 in current US dollars (World Bank, 2014).

${ }^{7}$ Average annual real GDP growth was 6.9\% in 1990-1999 and 7.2\% in 2000-2009 (growth rates have since declined.) This compares to $2.1 \%$ and $5.1 \%$, respectively, for all low-income countries over the same periods (World Bank, 2014).

${ }^{8}$ The proportion of the population living beneath the poverty line was $56 \%$ in $1992 / 93$ and $25 \%$ in 2009/2010. This represents an absolute decline of the population in poverty from 10 million to 7.5 million. The proportion of the population classified as non-poor but insecure had, however, increased from $33 \%$ to $43 \%$ over the same period and the Gini coefficient increased from 0.37 to 0.43 (MFPED, 2012: ix).
} 
states" focused primarily on agricultural development'. In the first decades after Ugandan independence, development policy continued to focus on agricultural development in the countryside (Mamdani, 1976), with what Ferguson (2012) calls 'strategies of restoring and developing peasant agriculture [that] were tightly bound up with fantasies of a communal and caring rural society that had to be restored'. Care for and assistance to the poor therefore continued to be seen as the responsibility of kin and community, best supported by improving rural livelihoods. In contrast to Southern African British colonies (especially the 'settler colonies') no 'poor law' tradition exists in Uganda, and the relatively fertile soil and predictable rainfall made food aid and input subsidies on the scale of those provided in countries like Malawi largely unnecessary. Food security was mostly a problem confined to the conflict-ridden and climatically more vulnerable North.

Public assistance to the vulnerable had been restricted to agricultural advisory services, district-level social development services, and a small number of 'social safety nets' in the form of school feeding schemes, a districtadministered disability grant, ${ }^{9}$ etc. World Bank and European Union reconstruction and recovery programmes in Northern Uganda, implemented from the early 2000s, included some social protection elements (public works, 'cash for work' youth schemes and Village Savings and Loans Associations), but were mainly targeted at the economically active and aimed at stimulating productive activity. These programmes nevertheless were significant, with large sums expended in the World Bank-financed Northern Uganda Social Action Fund (NUSAF) ${ }^{10}$ and EU-funded Northern Uganda Agricultural Livelihoods Recovery Programme. These interventions aimed at Northern Uganda-forming part of a broader Northern Uganda Reconstruction Programme (OPM, 2010) were implemented in the aftermath of decades of disruption caused by conflict, collapsing state infrastructure and were in part occasioned by the more precarious nature of agricultural livelihoods in this region. In their analysis of NUSAF, Golooba-Mutebi and Hickey (2010), make clear the 'exceptional' nature of the development efforts in Northern Uganda:

'Despite Uganda's success at 'mainstreaming the poverty agenda' in national policy processes via the PEAP and its relatively extensive system of decentralised governance, NUSAF was not integrated into either, with line ministries and government both rejected as the main channel for the project...' (Golooba-Mutebi and Hickey, 2010: 1225).

\footnotetext{
${ }^{9}$ This grant is not a cash grant available to individual persons with disabilities, but is rather aimed at organised groups for self-help and income-generating activities, etc.

${ }^{10}$ The first NUSAF, known as NUSAF I (funded to the tune of \$133m) ran from 2003 to 2009 and NUSAF II, with a budget of $\$ 100 \mathrm{~m}$ started in late 2010 .
} 
This indicates that the Northern Uganda programmes were generally seen (and treated) as exceptional, existing outside broader social protection policy, and did not serve as de facto pilots for social protection programmes in the rest of the country, or to have seen much (if any) involvement from the social development bureaucrats that feature centrally in this paper.

A recognition of the state as a primary agent in ensuring social safety nets, beyond supporting the 'development' of peasant and commercial agriculture, has only emerged after 2002. For most of the period since Museveni and his National Resistance Army ${ }^{11}$ took power in 1986, Uganda pursued a marketfriendly and growth-oriented development policy. The mid-1990s to the early/mid-2000s is often referred to as 'the poverty eradication era', when poverty featured centrally in development thinking. During this period the Poverty Eradication Action Plan (PEAP) of 1997 (MFPED, 1997) signalled a significant shift that placed poverty reduction at the core of Ugandan development policy (Mugambe, 2011), but social assistance and 'social safety nets' remained very marginal as potential anti-poverty measures. From the mid2000s the poverty agenda was increasingly displaced by a renewed emphasis on 'growth and prosperity' (Hickey, 2012), but social protection and cash transfers also appeared on the agenda, as described below.

\section{Social protection appears on the policy agenda through donor agenda-setting (2002- 2006)}

The notion of 'social safety nets' received regular mention in development planning documents, but remained at the margins of development policy throughout the 'poverty eradication era' of the mid-1990s to the early/mid2000s. Social protection in a more defined and substantial sense only appeared on the policy agenda from the early 2000s onwards, largely through the efforts of DFID, a number of civil society organisations, and a small group of social development bureaucrats. During this period donors were unambiguously the primary proponents of and agenda-setters on cash transfers, but they invested heavily in securing domestic political 'buy-in' and 'recruiting' supportive bureaucrats in their efforts to secure cash transfers on the Ugandan development policy agenda.

\footnotetext{
${ }^{11}$ The National Resistance Army (NRA) would soon after become the National Resistance Movement (NRM), which ruled under a form of 'no party democracy' until competitive Presidential elections were introduced in 1996 and multiparty legislative elections in 2006. It remains the majority party in Parliament and Museveni remains President.
} 
The second PEAP revision of 2004-PEAP III (MFPED 2004), which was produced after some donors and social development bureaucrats had started actively promoting social protection (see below), made some mention of noncontributory social assistance targeted at the poor and vulnerable. However, it remained couched in 'social safety nets' language and the proposed programmes were restricted in scope and for the most part were not envisaged to take the form of cash transfers. Few became policy priorities or were funded in subsequent national budgets (Hickey et al., 2009: 63-64).

In 2002, two major developments helped establish social protection on the policy agenda, although it would be years before this translated into tangible policy commitments and nearly a decade before a cash transfer pilot was finally launched.

The first development was the creation of a Social Protection Task Force (SPTF). The SPTF was housed in the MGLSD and included social development bureaucrats, as well as officials from the MFPED, other Ministries, the Office of the Prime Minister, and representatives from NGOs and donors (Grant, 2006; ESP, 2013). It appears to have received substantial technical support from DFID, although the exact nature of this support is not clear. ${ }^{12}$

Around the same time, the first NUSAF programme was agreed upon and launched. Elements of social protection were finding their way into reconstruction and development projects in Northern Uganda, apparently in large part owing to the initiative of the World Bank, as described earlier. These did not include cash transfers. As indicated earlier, however, it operated separately from broader Ugandan development initiatives and appears to have been conceived primarily as a response to the very specific challenges of postconflict conditions in the North. It was also a World Bank-financed programme and MGLSD bureaucrats had little to no operational involvement (see earlier discussion).

The SPTF's activities (such as commissioned research and consultative meetings) were funded and supported by DFID and can be seen as the start of a deliberate and extensive agenda-setting exercise. ${ }^{13}$ In a report for DFID the SPTF is described as a major component of the first stage of DFID's efforts to promote social protection in Uganda, which was focused on 'establishing SP as

\footnotetext{
${ }^{12}$ Unfortunately, a full history of the SPTF is not available in the published literature and extensive data on this important development was not collected during the fieldwork for this research. This is an area in which further research is required.

${ }^{13}$ Again, the exact details of DFID's support to and involvement in the SPTF process are not available at this time, but has been identified as an area for further research.
} 
a policy agenda' (Hickey et al., 2009: 19). Furthermore, the SPTF was described as having been 'designed to act as the champion of SP within [the Government of Uganda], initially by securing a policy focus on SP within the third Poverty Eradication Action Plan'. The task force's first major output was a report identifying a wide range of 'micro-initiatives' in existence, but noted that these operated in a policy vacuum and demand for social protection vastly outstripped supply. It recommended a strengthened regulatory framework and a range of interventions from tax-financed minimum income guarantees to the expansion of contributory social security (Devereux et al., 2002). ${ }^{14}$ At the same time, civil society voices were starting to call for an increased focus on social protection in development and poverty reduction. The first Chronic Poverty Report (CPRC Uganda, 2005) represented one of the earliest efforts by civil society to promote social protection as a core element of the development agenda, arguing that evidence from other low-income countries suggested that social protection measures were both desirable and affordable.

The second important development of 2002 was the production of the first official government document to extensively treat social protection as a policy response to extreme and chronic poverty, the Social Development Sector Strategic Investment Plan (SDIP). Even the SDIP largely reflected the prevailing emphasis on livelihoods and improved income-generating opportunities for the poor, but also called for a 'strengthened institutional and regulatory framework for social protection' (MGLSD, 2003: 10). It further envisaged specific support and 'safety nets' aimed at 'people in difficult circumstances', including such vulnerable groups as orphans, child labourers, people with disabilities, those affected by HIV and the elderly (MGLSD, 2003: 14). These early efforts by donors and social development bureaucrats to embed social protection in the development policy agenda had some success, but faced substantial resistance, especially from technocrats in the MFPED, who had overall responsibility for policy development and planning processes. In summary: social protection appeared on the policy agenda, but did not become a policy priority for the Government of Uganda as a whole.

Grant's (2006: 7-10) analysis of the effectiveness and influence of the SPTF process (the most extensive documentation of this process available) is based on interviews with members of the task force from all the represented sectors, as well as interested observers within the Ugandan government. At the time the process was perceived as having 'fallen flat', with momentum having been lost and the SDIP failing to be operationalised. She identifies a number of

\footnotetext{
${ }^{14}$ Two of the lead researchers were from the University of Sussex's Institute for Development Studies and the third from the Kampala-based research NGO Development Research and Training.
} 
deficiencies in the process. Attempts to influence sectors during the PEAP revision of 2003-4 largely failed and sectors did not 'really engage with the concept or ideas presented through the SPTF' (2006: 8). Very little direction was provided by the MGLSD as lead ministry, compounded by the Ministry's 'lack of clout' as a result of its reputation as weak and ineffective (2006: 9). Furthermore, two major donors were perceived as being at odds with one another with DFID's 'vulnerability and poverty framework' and the World Bank's 'social risk management (SRM) framework' seen as competing and incompatible agendas - some of Grant's MGLSD informants even suggested that the World Bank had been dismissive of ideas developed by DFID (Grant, 2006: 8). She appears to consider the key failures a 'lack of leadership' and 'insufficient efforts' to further the social protection agenda within the Ugandan government:

'One informant in the Ministry of Finance observed that the presentation of what was actually needed wasn't thoroughly or convincingly detailed - or perhaps more importantly, argued. Despite having the commissioned support studies, the MGLSD did not push the issues forward aggressively. ...without clear leadership within the Ministry of Gender, social protection issues simply didn't make an impact. He acknowledges that there were some very good ideas ... but they simply [had] not been picked up. Similarly, the ... [MGLSD officials] expected that once information on social protection had been collected, analysed and documented, uptake and buy-in by the different relevant institutions would be automatic' (Grant, 2006: 9).

It is difficult to judge how important 'failures' in these early agenda-setting and promotion efforts of donors and bureaucrats were relative to a lack of receptiveness among sceptical technocrats and politicians. Paul Onapa, at the time of fieldwork for this research a senior manager at Development Research and Training (DRT $)^{15}$ - a research agency with a focus on chronic poverty since its founding in 1997 and very active in promoting social protection in Ugandadescribed the appetite for social assistance and cash transfers during this period as extremely limited, and attributed this to the prevalence of fears that it would 'breed dependency' on the state, near-unanimity among financial technocrats that it would be unaffordable and unsustainable, as well as its divergence from a firmly entrenched conception of the state's developmental role as one of creating an 'enabling environment' rather than addressing poverty and

\footnotetext{
15 Onapa had about a decade of experience in poverty-focused civil society organisations, a significant portion of which he spent at DRT where he had primary responsibility for social protection-related research and advocacy work - also forming part of the team that designed the first proposed cash transfer pilot (see below). In 2014 he accepted a position with the Ministry of Gender, Labour and Social Development.
} 
vulnerability through direct assistance. ${ }^{16}$ In light of this, along with donors providing mixed signals and the perceived divergence between DFID and the World Bank - a 'joint assistance strategy' from Uganda's major donors (ADB et al., 2005) made no mention of social protection-it is not surprising that the champions of social protection met with limited success.

Since social development bureaucrats played an important part in the SPTF and were responsible for the production of SDIP, the role of bureaucrats clearly started to become important even in this donor-dominated period. It would be inaccurate to characterise the agenda-setting efforts of DFID, supportive social development bureaucrats, and to some extent civil society during this period as entirely unsuccessful. As the references to safety nets in PEAP III demonstrate, social assistance had penetrated the policy discourse and were to some extent 'on the agenda', even if this did not translate into significant policy reforms. In addition, the Ugandan government became party to the Livingstone Call for Action, a declaration issued at an African Union conference in Zambia in 2006, which called on African states to produce comprehensive social protection plans.

But despite social assistance appearing on the policy agenda, no real policy reform occurred for several years and social development bureaucrats championing expanded social protection made limited headway. No comprehensive national social protection plan was developed in line with the Livingstone Call for Action. This seems unsurprising given that the thenMinister of Gender, Labour and Social Development, Zoe Bakoko Bakoru, had reportedly argued at the conference that "the ever-present fear of the cost of social protection programmes makes them unattractive" (HelpAge International, 2006: 19$).{ }^{17}$

The limited progress made by proponents was evident in the fact that programmes either did not progress beyond the design stage or were simply not awarded the necessary budgetary appropriations. Development plans and policy documents from the 'poverty eradication era' reveal the continued dominance of a livelihoods-oriented development paradigm which emphasised helping the poor become self-sufficient and productive, rather than directly supporting income and consumption. It is only in the more recent overarching development

\footnotetext{
${ }^{16}$ Interview, Paul Onapa (20 January 2014).

${ }^{17}$ Notably, at the time of this research few informants referred to the Livingstone Call for Action in interviews, except the Chairperson of the Parliamentary Forum, who cited it as one among a set of international obligations that underscored her optimism about the future of social protection in Uganda (Interview, Flavia Kabahenda, MP, 4 February 2014). It certainly did not appear to be perceived as a very significant moment in the history of welfare and social policy reform in Uganda.
} 
policy documents, the National Development Plan (GoU, 2010) and Vision 2040 (GoU, 2013)-published after the major programmatic commitment of ESP/SAGE had been approved - that social protection was identified as a major policy priority.

As far as can be determined from the available data, this period was one essentially of donor agenda-setting, with enthusiastic but relatively low-level bureaucratic involvement. Despite the SPTF's nominal inter-ministerial character and Permanent-Secretary-level representation on the task force, most significant work appears to have been done by lower-level bureaucrats and outside consultants. Donors (especially DFID) were the major source of ideas and policy proposals. Ideas and language related to social protection found their way into major policy documents, but seem to have largely been the product of compromises reached in consultative document-production processes, rather than significant penetration of institutions like the MFPED and the Presidency by the emerging social protection agenda. Supportive bureaucrats remained largely confined to the MGLSD - at the time widely perceived as weak, lacking in influence, and not one of the 'core development' Ministries. ${ }^{18}$

\section{Towards policy reform: programmatic proposals and continued promotion of cash transfers with bureaucratic support (2006-2010)}

During this period, donors remained the primary driving force of policy reform and primary proponents of cash transfers, but had already secured substantial bureaucratic 'buy-in' and supportive bureaucrats increasingly became the principal agents pursuing political support for cash transfers. Donors like DFID were also starting to think actively about the failure of their efforts to secure domestic political support and even commissioned studies aimed at informing their efforts to influence policy on social protection in Uganda and elsewhere, for example the study by Hickey et al. (2009). As will be shown below, advocacy and building political support became a central concern, and bureaucratic advocacy would be central to DFID's strategy.

Since a central contention of this paper is that bureaucratic advocacy was a crucial success factor, it is important to consider how influential the Ugandan bureaucracy was relative to political leaders, and social development bureaucrats

\footnotetext{
${ }^{18}$ The broader history of the evolution of social protection policy is addressed in Grebe and Mubiru (2014), and some of the specifics of bureaucratic influence in this evolution require further research.
} 
relative to technocrats in the Presidency, Office of the Prime Minister and, crucially, the Ministry of Finance. Unfortunately, the literature on the Ugandan bureaucracy is extremely limited (and so is the data available on the specific bureaucratic actors during this period). Notably, there is almost nothing available on intra-bureaucratic policy rivalry, apart from Grant (2006), who showed that the MGLSD was at the time considered weak and lacking in influence, especially when compared to the MFPED. Some of the available literature (for example, Bitaliwo, 2014), suggests that while bureaucratic capacity had been rising in the post-colonial era, the Ugandan bureaucracy lacked independence and was subject to political interference. He notes,

'[This political element] ... is very critical in defining the direction the bureaucracies can and shall take in tackling the implementation of the public good. It is this political element therefore that makes reform efforts more strategic in the direction of the policies of the government for the benefit of the governed' (Bitaliwo, 2014: 47).

Byaruhanga (2013: 19) further asserts that an extremely high level of control was exerted by the executive over both the bureaucracy and the other arms of government (the judiciary and legislature). If correct, these assertions would chime with the claim made by numerous respondents for this research that 'official policy' was not the primary factor driving what happened in Ugandan policy implementation. Rather, politics determined outcomes, and when a policy was perceived as enjoying political support at the highest level, it was more likely to be funded and implemented than otherwise. This also appears to be what donors later realised when they shifted their attention increasingly to securing high-level political support (see later in this section). Despite these suggestions of political capture of the bureaucracy - which have some meritother researchers have suggested that high levels of public information can act as a powerful deterrent to the corrupt use of funds and enhance the quality of service delivery in Uganda (Reinikka and Svensson, 2011), a further lesson that donors appear to have learnt and that is reflected in their actions described in the next section. The evidence presented in this section suggests that despite the relative weakness of the MGLSD (Grant, 2006), donor support for bureaucratic capacity in the MGLSD allowed social development bureaucrats to become effective advocates for policy reform. Coupled with explicit efforts to secure high-level political support, progress in policy reform could be attained that had not been possible before.

From 2006, the SPTF decided to focus on cash transfers as the primary social protection mechanism it sought to promote (Hickey et al., 2009). A Memorandum of Understanding between DFID and the Government of Uganda to design and pilot a cash transfer scheme was signed in late 2006. The SPTF 
commissioned external consultants to design the pilot (with funding and support from DFID), with DRT as the lead partner in a design team that also included international consultants. It produced a comprehensive proposal, which was accepted and published by the SPTF in June 2007 (MGLSD, 2007). This was a period characterised by significant enthusiasm for pilot cash transfer schemes on the part of DFID. It had funded similar pilot schemes in other countries in the region-notably Zambia, where a cash transfer pilot was well underway, although that pilot increasingly faltered owing to lack of enthusiasm and even outright opposition from Zambian political leaders (see Kabandula and Seekings, forthcoming) - and DFID was presumably seeking to replicate these efforts in Uganda.

Two of the proposed pilot's primary aims would be to 'demonstrate the desirability and feasibility of such a scheme' and to 'win political support' for cash transfers (MGLSD, 2007: vii). The team clearly sought to base the pilot design on sound evidence, as shown by the series of background papers commissioned for it (including a vulnerability assessment, reviews of international literature and simulations, and models to quantify expected impacts). It also consulted widely with civil society and academia. The published design clearly showed the influence of civil society and research groups that were concerned with 'chronic poverty' at the time. The terms of reference called for a 'cash transfer pilot scheme to address chronic poverty' (my emphasis) and the design document extensively cited the first Chronic Poverty Report (CPRC Uganda, 2005) ${ }^{19}$ referred to earlier.

The SPTF had donor, civil society and wide government representation, but its outputs were mainly driven by MGLSD bureaucrats, drawing on the expertise of external consultants (paid for by donors) and ideas originating with or relayed by donors. Despite the still primary role of donors at this stage in promoting a social protection agenda (in this case, specifically cash transfers), the SPTF's leading role in commissioning the design of a pilot cash transfer and in seeking approval from the Finance Ministry can be seen as the start of bureaucratic coalition-building around cash transfers. This coalition-building becomes both more prominent and more successful at a later stage, as described in the next section.

Despite the recognised need to win political support for cash transfers, the SPTF and their consultants appeared to underestimate the opposition even a pilot cash transfer scheme might face and the document made little effort to present cash transfers as anything other than a mechanism to address poverty directly. For

${ }^{19}$ Note that CPRC Uganda and the DRT comprised an overlapping set of people, closely linked with the Manchester-based Chronic Poverty Centre. 
example, it prominently presents estimates of the impact on the poverty gap of various options. The design envisaged targeting beneficiaries in the lowest decile of consumption expenditure and proposed a transfer of UGX 18,000 per household (US\$10.58 in June 2007) plus supplementary transfers of UGX 2,000 for every child under 18, elderly person (60 and older), and person living with a disability in the household up to a maximum of five supplementary transfers. It proposed six pilot districts selected on the basis of a multi-criterion ranking based on demographic characteristics (the share of vulnerable people in the district population). It further proposed relatively complex eligibility criteria for individual households and a ranking procedure for selecting from eligible households. The proposed scheme included 'soft conditionalities' in an attempt to establish links between the transfer and health, education and nutritional outcomes through 'moral suasion' and 'opt-in incentives' to meet a package of health and schooling commitments (MGLSD, 2007: 15-16).

The soft conditionalities included in the design may very well reflect an attempt on the part of the donors, social development bureaucrats, and their partners to 'sell' the idea of cash transfers to a political and policy elite expected to be sceptical of 'hand-outs' that require little or nothing in return from beneficiaries; conditionalities are widely seen as having rendered social assistance more palatable to the middle classes in Latin America. ${ }^{20}$ But the opposition encountered when the SPTF and MGLSD moved to put the pilot scheme into action was unexpectedly strong. The pilot faced significant resistance from Finance Ministry officials, which Paul Onapa of the DRT (and member of the original design team) attributed to 'hard-core' (neoliberal) economic ideology in the MFPED:

'This design was not taken up ... because then social protection was just coming up... But also because this was challenging an economic model that existed. The technocrats [in the MFPED] believe in hardcore [neoliberal] economics and also harbour what I call elite attitudes towards the poor. We could see this from statements from the governor of the central bank, the Minister of Finance. These are people [who believed] that poor people are poor because of their own actions, and therefore they must work harder to lift themselves out of poverty. They did not believe the state had a role in helping to lift the

\footnotetext{
20 Although it should be noted that informants focused more on the 'fashion' for and international experience with conditional cash transfers than on their potential political utility in discussions of this issue. However, see the quote from Paul Onapa below for some suggestion that proponents were aware that unconditional 'hand-outs' may be less politically acceptable than conditional transfers.
} 
poor out of poverty using measures that are not conditioned on [the poor] doing anything' (interview, Paul Onapa, 20 January 2014). ${ }^{21}$

Stephen Barrett (leader of the technical assistance team based in the Social Protection Secretariat created within the MGLSD to implement the ESP) also attributed the failure of the first pilot to its 'poverty focus' and negative elite attitudes to cash transfers:

'This is why the first programme failed: it was a poverty-targeted programme, it was designed to use proxy means testing and a conditional cash transfer programme, all around poverty. ... [Decision-makers] didn't see cash transfers as an answer to poverty, they saw hard work and economic growth and [the poor] 'getting off their backsides' as the answer to poverty' (interview, Stephen Barrett, 13 January 2014).

The then-Minister of Finance, Dr Ezra Suruma (an economist by training), blocked implementation of the project by refusing to issue the legally required 'certificate of financial implication', without which even donor-sourced but government-administered expenditure is impossible. The Minister's apparent concerns were over the 'affordability of the project over the long term and its donor-led character' (Hickey et al., 2009: 65). According to Paul Onapa and John Bosco Mubiru (also of DRT), sustainability was indeed a serious concern. ${ }^{22}$ Both financial technocrats and their political principals were aware that once implemented, even a pilot scheme would be difficult to roll back, potentially creating an open-ended financial commitment if donor support ended. ${ }^{23}$

The SPTF and the designers of the pilot had apparently simply not anticipated the level of resistance the plan would encounter and too little groundwork had as yet been done to build awareness of and political support for it. The proponents of a cash transfer pilot had no choice but to go back to the drawing board, this time setting out on an extensive and well-planned advocacy exercise, alongside attempting to design a more politically acceptable pilot scheme. The social development bureaucrats in the MGLSD became increasingly central to the advocacy exercise.

Proponents now saw building political support for social protection in general, and a cash transfer pilot in particular, as critical, says Beatrice Okillan (a longstanding official in the MGLSD and later Policy and Learning Manager in the

\footnotetext{
${ }^{21}$ The reference to the poor 'doing something in return' probably refers more to 'work' than to conditionalities related to health, schooling, etc. in this context.

${ }^{22}$ Interviews, John Bosco Mubiru and Paul Onapa (20 January 2014).

${ }^{23}$ Interview, Stephen Barrett (13 January 2014).
} 
Social Protection Secretariat administering ESP/SAGE). ${ }^{24}$ A senior DFID official and a DFID-contracted consultant explained that the agency now understood that merely offering funds for an initiative would not guarantee its acceptance, particularly when elite attitudes in general were not favourable to social protection and financial technocrats and politicians were (understandably) concerned over creating long-term liabilities. ${ }^{25}$

This represents a critical turning point at which donors realised that domestic politics is a central issue to be addressed in pursuing their agenda, and that supportive bureaucrats 'embedded' in the state whose developmental priorities it wishes to influence were among their most important assets alongside the direct leverage of financial muscle. The commissioned study mentioned in the opening paragraph of this section in part reflected this realisation.

While winning political support for cash transfers had previously been an intended and expected outcome of implementing a pilot, it was now seen as a prerequisite for even getting a pilot off the ground. This increased focus on building support is reflected even in the name given to the programme that was eventually to be implemented: the Expanding Social Protection programme, of which the SAGE cash transfer pilot is a mere a component, albeit arguably the most important and certainly the most costly.

A new set of consultants, led by Maxwell Stamp Plc., was engaged (although retaining DRT as part of the team) to design a new pilot. ${ }^{26}$ The proposed design for what eventually became the ESP and SAGE differed from the previous proposal in several respects. It was larger (fourteen pilot districts instead of six, but still selected based on a vulnerability analysis) and included both a povertytargeted and 'categorical' or 'universal' transfer (as opposed to a pure povertytargeted formula) while dropping any form of conditionality. ${ }^{27}$ The programme was no longer merely expected to demonstrate the feasibility and effectiveness of cash transfers, but had extensive (and budgeted for) advocacy and capacity development components intended to build a comprehensive 'social protection system'. Its aims explicitly included 'embed[ding] a national social protection

\footnotetext{
${ }^{24}$ Interview, Beatrice Okillan (13 January 2014).

${ }^{25}$ Interviews, Stephen Barrett and Rachel Waterhouse (13 January 2014).

${ }^{26}$ It seems somewhat paradoxical that the introduction of foreign consultants coincided with explicit efforts to secure domestic political support and avoid the perception of the new pilot being 'donor-driven'. This paradox cannot be fully resolved using the available data, but may reflect a desire for a more 'technically convincing' design. However, there is no direct evidence from interviews for this hypothesis. It is a question that should be addressed in further research.

${ }^{27}$ The relative lack of interest in conditionalities in Uganda as a potential source of political support remains somewhat of a mystery, with informants giving contradictory and sometimes implausable explanations. This is another area calling for additional research.
} 
system, including Direct Income Support, ${ }^{28}$ as a core element of Uganda's national policy, planning and budgeting processes' (Kasaija, 2011) and to develop social protection capacity in the MGLSD (Bukuluki and Watson, 2012: 13). Winning support for and embedding social protection in the Ugandan policy landscape would be pursued partly through the implementation of the pilot, but would also include active lobbying across a range of institutions and sectors of society and building institutional capacity within the Government of Uganda to implement social assistance schemes. For example, donors would fund study tours for officials and politicians to be exposed to the experiences of countries that had implemented cash transfer schemes, and funding would be allocated to civil society organisations advocating expanded social protection. MGLSD officials would lead this lobbying and advocacy exercise.

In addition, the MGLSD and its donor partners now sought high-level political buy-in from the outset, placing its proposal before Cabinet rather than attempting to forge ahead with implementation subject to approval from the Finance Ministry. It was understood that in the context of Uganda's personalised politics, gaining the support of Museveni and his inner circle was critical, and even several years after implementation of the pilot had started senior officials were continuing to actively pursue the President in an attempt to win his support. (Officials responsible for the ESP even attempted to woo the President via his wife, Janet Museveni, who was also the Minister for Karamoja. ${ }^{29}$ ) It was widely believed (and a number of informants expressed this view) that important political decisions are made by a very small circle of influential 'insiders' who had the ear of the President. ${ }^{30}$ DFID even commissioned a report from a respected Ugandan political scientist perceived as very well-connected, Frederick Golooba-Mutebi (the same one cited above), aimed at developing an appropriate strategy for winning political support, ${ }^{31}$ and sought to establish which individuals within the corridors of power had most influence over Museveni and Cabinet policy. ${ }^{32}$

When the second proposed pilot finally came before the Cabinet in 2010, a Cabinet sub-committee was established (which, in addition to the Minister of Gender, Labour and Social Development comprised several senior ministers

\footnotetext{
28 'Direct Income Support' is the preferred terminology of the MGLSD when referring to cash transfer schemes, possibly reflecting an awareness of negative connotations attached to the latter.

${ }^{29}$ Interview, Stephen Barrett (13 January 2014).

${ }^{30}$ This view is consistent with Golooba-Mutebi and Hickey's (2013), assessment of Uganda's political settlement as primarily of the 'dominant leader form' and much of the political science literature on Museveni-era Uganda.

${ }^{31}$ Interview, Rachel Waterhouse (13 January 2014).

${ }^{32}$ Anonymous informant.
} 
responsible for areas described as 'real' or 'hard' development policy, including the Ministers of Finance and of Works and Transport) to evaluate the proposal. The SPTF and design team went to considerable lengths to address concerns raised by ministers on the sub-committee. Cabinet approved the ESP/SAGE programme in June 2010, and even agreed to the requirement of 'counter-part funding' (i.e. that a-small-portion of the funding for the programme would come from the Ugandan fiscus).

In a fortuitous development, Syda Bbumba, who had been Minister of Gender, Labour and Social Development from 2006 (i.e. during the period when the first proposal of a pilot cash transfer had failed to win support), had been appointed Minister of Finance in February 2009. Her presence on the Cabinet subcommittee and the clout inherent in her position, together with the fact that certain senior MFPED officials (including a Minister of State ${ }^{33}$ in the MFPED, Fred Omach) were seen as having become sympathetic to cash transfers, were cited by informants as important contributors to the proposed pilot winning Cabinet support and obtaining the necessary clearance from the MFPED. DFID's senior social development advisor, Rachel Waterhouse, described this as the single most important factor for the proposal's success. ${ }^{34}$

When asked why the proposed ESP did not meet the same fate as the first proposed pilot, a number of factors were highlighted by informants interviewed for this study. These are explored in Grebe and Mubiru (2014), but included greater familiarity with cash transfers (which had become more prominent in international development circles and were being increasingly promoted by institutions like the World Bank), more evidence of their effectiveness from other countries (Latin America, particularly, but also Southern Africa), that greater care had been taken to address concerns pre-emptively and, crucially, the support of Minister Bbumba. Perhaps the most candid response came from Stephen Barrett, who attributed the success of the new proposed pilot to its lack of a 'poverty focus'. He explained that a deliberate strategy had been adopted to move away from a general focus on addressing chronic poverty and vulnerability, to a focus on vulnerable groups, in particular the aged, a group traditionally considered entitled to support. The proponents of the pilot exploited a sense of 'public shame over poverty among old people':

'We moved away from the generalised poverty discussion and focused on a vulnerable group that we felt we could get buy-in for and justify

\footnotetext{
${ }^{33}$ In Uganda, where terminology often mirrors the British system, Ministers of State are essentially deputy or junior ministers-i.e. they form part of the political leadership of the Ministry, while the administrative heads of Ministries managing the civil service are known as Permanent Secretaries.

${ }^{34}$ Interview, Rachel Waterhouse (13 January 2014).
} 
[support for]. We moved away from the general [poor] population that many people believed [were poor as a result of their laziness] to a group where no-one could really claim that they should work harder, which is old people. And we built up a consensus around the programme which links to issues of 'the role that old people played in building the country', narratives around veterans of the bush war... the care old people provide to orphans [etc.]... [We] built up evidence around the poverty and vulnerability of old people. And that chimed with the public, it chimed with the media ... and it chimed with traditional values on respect and care for the elderly' (interview, Stephen Barrett, 13 January 2014).

While social development bureaucrats had long embraced social assistance, more than one informant pointed out that the ESP (coming as it did with substantial donor-provided resources) represented a huge opportunity for a ministry that had traditionally not been very influential. As is the case in many developing countries, it had historically been overshadowed by 'strategically important' ministries, like defence, and the higher-spending social ministries of health and education. The opportunity to oversee a major development project with a significant budget, and to build substantial capacity within the department, represented a real chance for an increase in the stature and influence of the Ministry. This may partly explain the enthusiasm with which social development bureaucrats embraced their newly-central role as champions of cash transfers and welcomed their increased capacity to pursue a social protection agenda. This is therefore a case of both ideological and pragmatic bureaucratic 'buy-in' to an initially donor-driven agenda.

The MGLSD bureaucrats' continuing strong commitment to social protection can be seen in the product of a parallel process, the drafting of a second iteration of the Social Development Sector Strategic Investment Plan (SDIP 2), which attempted to articulate how the 2010 National Development Plan's social protection commitments could be translated into budgetary appropriations. A stated priority of the plan was 'extending social protection services to vulnerable persons (older persons, children, youth and [people with disabilities])' (MGLSD, 2011: ix). In contrast to the first SDIP and earlier policy documents, cash transfers ('direct income support' in Ugandan parlance) was explicitly listed as a core component of the broader social protection strategy, eschewing the vague language of 'social safety nets'.

It appears that a politically astute design, a successful campaign of lobbying by donor-supported bureaucrats (which was continuing vigorously at the time of 
this research), ${ }^{35}$ deliberate inclusiveness in the management of the programme (Finance Ministry officials and other senior technocrats serve on the subcommittee responsible for implementation) and extensive efforts to generate and document evidence of the impacts of the cash transfer pilot $^{36}$ helped build momentum and support for cash transfers. The Ugandan government's commitment to financially contributing to the pilot, and its central role in the programme's administration were symbolically important and allowed donors to claim success in achieving 'government ownership'.

\section{Bureaucrats as advocates: institution- building, capacity-building and promotion of cash transfers through the ESP and SAGE (2010-2013)}

Between 2006 and 2010, bureaucrats became central, essential, and arguably even the primary actors in the political promotion of cash transfers in Uganda. This centrality became even more pronounced after 2010. The ESP was called a 'strategy to change attitudes towards social protection' by one informant. ${ }^{37}$ Resistance to social assistance nevertheless continued to be strong from certain quarters.

After the approval of the ESP in 2010, preparations for the implementation of the SAGE pilot started with the creation of a new Social Protection Secretariat within the MGLSD. Implementation was overseen at a higher level by the Social Protection Sub-Committee (essentially the successor of the SPTF), which continued to be coordinated by the MGLSD with representation from other Ministries, donors as well as civil society and academia. ${ }^{38}$ The Secretariat operated with a high level of autonomy from the rest of the Ministry (for example, its budget and finances were managed separately from general ministerial procedures, allowing for greater flexibility in recruitment, tenders for external service providers, etc.). ${ }^{39}$ The Secretariat's offices were separate from the MGLSD's main offices in Kampala, and it was unusually well-resourced and well-capacitated, in no small part thanks to substantial technical assistance provided by DFID-appointed contractors, including key personnel responsible

\footnotetext{
${ }^{35}$ Interviews, David Tumwesigye (13 January 2014); Stephen Kasaija (17 January 2014).

${ }^{36}$ Interviews, David Tumwesigye (13 January 2014); Beatrice Okillan (13 January 2014)

${ }^{37}$ Interview, David Tumwesigye (13 January 2014).

${ }^{38}$ It was chaired by the Permanent Secretary of the MGLSD.

${ }^{39}$ Interview, Pius Okello (5 February 2014).
} 
for a range of functions. ${ }^{40}$ Examples include Stephen Barrett (Team Leader: Technical Assistance), who in practice had overall operational responsibility, and Georgia Rowe, who served as Social Protection Policy Advisor from 20102013, and who managed policy and advocacy activities - both of whom were formally employed by Maxwell Stamp Plc. in terms of the latter's contract with DFID. These external consultants were firmly embedded in the Secretariat and in practice operated as if they were regular MGLSD employees and as part of an integrated Government of Uganda social protection team reporting to the head of the Secretariat, who in turn reported to the senior management of the MGLSD and whose work was overseen by the Social Protection Sub-Committee.

The majority of the Secretariat's staff were Ugandan, recruited from within the MGLSD, including many experienced social development officials (for example, Beatrice Okillan, a senior figure in the Secretariat). The donors' strategy was to provide direct technical support, but also to facilitate skills transfer, develop a cadre of experienced officials, fund training activities in order to build the requisite capacity not only in policy-making (it set out to facilitate a policy development exercise the content of which it sought to influence), but also to continue with implementation of the pilot and, it was hoped, eventually a range of domestically-funded social assistance schemes. ${ }^{41}$ Donors largely retreated into the background once the implementation of ESP and SAGE started, with social development bureaucrats becoming the frontline implementers of and advocates for social protection and cash transfers. Somewhat unusually, DFID and IrishAid branding was seldom prominently displayed on ESP/SAGE promotional materials aimed at domestic consumption, while in contrast Government of Uganda, MGLSD and ESP branding was very prominent. ${ }^{42}$

Successful implementation of the SAGE pilot and in the process generating evidence that a government-administered cash transfer programme could succeed and produce the intended impacts was a significant component of this strategy. It was also expected to 'generate demand' among the population. Stephen Kasaija, head of the Social Protection Secretariat said:

\footnotetext{
${ }^{40}$ It was not unusual for donor-funded but government-implemented programmes in Uganda to have core technical staff supplied by donors or contractors of donors.

${ }^{41}$ Interviews, Rachel Waterhouse (13 January 2014) and Caroline Kego Laker (28 January 2014).

${ }^{42}$ This is the personal observation of the author and that it is a deliberate strategy has not been confirmed by informants, although Stephen Barrett stated that there is a deliberate strategy to allow the Ugandan government and politicians to 'claim ownership of' and 'take credit for' the programme. Donor branding did feature prominently on reports, the website and similar materials aimed at least partially at a non-domestic audience.
} 
'Originally people ${ }^{43}$ didn't understand [social protection] and believed government couldn't [implement cash transfers], but when they go to the ground and really see how people's lives are changed [it influences their attitudes]. And the public has been very responsive - not only beneficiaries. ... We have been receiving many calls from local leaders saying we need this programme in our districts' (interview, Stephen Kasaija, 17 January 2014).

With the creation of the Secretariat, bureaucrats took formal responsibility for the promotion of cash transfers to politicians, technocrats and the general public as part of the programme. David Tumwesigye (Advocacy Advisor in the Secretariat) explained:

'The ESP programme is essentially a strategy that seeks to cause positive change in the attitudes of people to social protection in Uganda, particularly political leaders and senior technocrats who make key policy decisions. We use the evidence from [our] studies ... and the SAGE pilot ... to convince political leaders at the highest level and technocrats that social protection is a worthy investment ... so that those excluded from Uganda's impressive economic performance can benefit from and contribute to Uganda's socioeconomic transformation' (interview, David Tumwesigye, 13 January 2014).

As previously mentioned, a primary goal of the ESP was 'embed[ding] a national social protection system that benefits the poorest as a core element of Uganda's national policy, planning and budgeting processes' (ESP, undated) and an important component was the drafting of a Social Protection Policy Framework for Uganda through a process of wide consultation. DFID also funded a Parliamentary Forum on Social Protection, a vehicle for supportive Members of Parliament to promote social protection, and specifically to mobilise support in the legislature for the SAGE pilot and a national social pension. ${ }^{44}$

DFID (2013: 2) identified three intended outputs beyond the pilot itself: (1) institutional capacity for social protection policy-making and implementing social transfers; (2) a national social protection policy; and (3) increased understanding of and commitment to public investment in social protection. This third output was primarily pursued through the work of the bureaucrats whom it

\footnotetext{
${ }^{43} \mathrm{He}$ appeared to be referring to members of the political and policy elite here, including technocrats and politicians.

${ }^{44}$ Interview, Flavia Kabahenda, MP (4 February 2014).
} 
funded and provided with technical assistance, but who further appeared in interviews to be autonomously (and strongly) committed to the social protection agenda.

This raises the question, were the bureaucrats who advocated cash transfers mere agents of donors, or was this rather a case of alignment of purpose between donors and a section of the Ugandan bureaucracy? The evidence presented in this paper largely supports the latter conclusion. While the process might appear to have been donor-driven, initially probably was, and donors have certainly been key drivers, the level of participation and 'buy-in' from social development bureaucrats, certain other sections of the bureaucracy, civil society organisations and members of parliament was strikingly high. Most informants denied that the process continued to be dominated by donors. ${ }^{45}$

Implementation of the SAGE cash transfer pilot started in 2010, with the first payments made to beneficiaries in October 2011. The scheme was intended to reach 95,000 households over five years and by the end of 2013 had enrolled approximately 113,000 beneficiaries and paid out UGX 32bn (about US\$13m) in the fourteen original pilot districts (Okillan, 2014). Similar to the previouslyproposed pilot, districts were selected on the basis of the share of households considered poor and vulnerable. The selected districts cover a wide geographic area, although the less stable and very poor North was largely excluded, possibly because a range of existing reconstruction, peace-building and livelihoods schemes were in place in that region, including the World Bank-funded Northern Uganda Social Action Fund (NUSAF) and EU-funded Northern Uganda Agricultural Livelihoods Recovery Programme referred to earlier. ${ }^{46}$ One opposition legislator who represented a constituency falling within one of the pilot districts (Apach) attributed her district's inclusion to the involvement of donors in the design of the pilot, asserting that Apach, as an opposition stronghold, ${ }^{47}$ "would never otherwise have been selected for inclusion in a government programme". ${ }^{48}$ This confirmed that perceptions of patronage in

\footnotetext{
45 Interviews, David Tumwesigye (13 January 2014); Stephen Kasaija (17 January 2014); anonymous senior MGLSD official (23 January 2014); Alfred Nuamanya Buhitsya (30 January 2014); Sarah Nahalamba (30 January 2014); Flavia Kabahenda, MP (4 February 2014).

${ }^{46}$ Little data on the efforts in Northern Uganda were collected during the fieldwork for this paper. The relationship between reconstruction and development projects in the North and broader social protection policy reform (and between the different donors and government officials involved in the respective processes) is an area deserving of further research and analysis, and is also addressed to some extent in Grebe and Mubiru, 2014).

${ }^{47}$ Uganda's first Prime Minister and later President, who again served as President for several years after the fall of the Amin regime, hailed from Apach. Since the reintroduction of multiparty parliamentary elections it has consistently elected opposition candidates.

${ }^{48}$ Interview, Lucy Ajok, MP (17 January 2014).
} 
development programmes existed in some quarters. (These perceptions may have been strengthened by the apparently quite arbitrary 'instruction' from Museveni that a fifteenth district, Yumbe, be added to the pilot in 2013, although social development bureaucrats insisted on interpreting this as a positive indication of Presidential support for the pilot.)

SAGE comprised two grants: the Senior Citizen Grant (SCG) - a universal ('categorical' or untargeted) social pension to which all persons aged 65 and older are entitled (60 and older in Karamoja) and a Vulnerable Families Grant (VFG), a poverty-targeted grant allocated to the $15 \%$ 'most vulnerable' households in each pilot district. The 'most vulnerable' households were identified using a vulnerability ranking system based on the ages, sex, disability status, and orphanhood status of household members. The vulnerability ranking methodology was designed with a view to reflecting labour capacity and dependency ratios, in what could be considered (in principle, rather technical terms) a variant of 'proxy means testing'. Amounts paid to beneficiaries were modest, even by Ugandan standards, with the SCG consisting (in early 2014 and according to the most recent available information at the time of writing) of a monthly payment of UGX 25,000 (equivalent to about US\$10) paid to each eligible elderly person. Grants were paid out in the form of mobile phone-based 'mobile money' through a private sector service provider (MTN, a South Africabased multinational telecommunications company and operator of the largest mobile phone network in Uganda). Enrolment was largely the responsibility of the private sector contractor (supervised by Social Protection Secretariatappointed officials), with limited documentary requirements, no biometric component (largely in order to save costs and to keep enrolment as simple as possible), ${ }^{49}$ and community-based verification of age-eligibility when potential beneficiaries lacked birth certificates or other documentation. The 'mobile money' delivery mechanism was perceived as having worked very well and efficiently, despite some initial problems with enrolments and the occasional need to revert to manual payment processing when network infrastructure failed. ${ }^{50}$

The pilot was funded by DFID and IrishAid to the tune of $£ 50.5 \mathrm{~m}$ and $£ 7 \mathrm{~m}$ respectively over the period 2010-2015 with some UNICEF technical support and subject to a requirement for Ugandan 'counter-part funding'. While initially failing to meet commitments, the Government of Uganda later committed UGX 2 bn (US\$ 800k). This appropriation was counted as a major victory by both social protection officials in the MGLSD and donors. While budget appropriations were constitutionally a parliamentary competency, the budget

\footnotetext{
${ }^{49}$ Interview, Stephen Barrett (6 February 2014).

${ }^{50}$ Interview, Pius Okello (5 February 2014).
} 
process in Uganda was dominated by the executive. A member of parliament who had served on the Budget Committee (Rosemary Nyakikongoro, MP) confirmed that it was extremely difficult for legislators to alter budget proposals once they had been submitted to Parliament for consideration and voting. She argued that lobbying earlier in the planning cycle was the only realistic way for legislators to substantially influence appropriations. ${ }^{51}$

Despite the extensive agenda-setting efforts and vigorous promotion of social protection and cash transfers already described, the approval and largely onschedule implementation of SAGE represented a considerable achievement in overcoming widespread scepticism and opposition. Uganda was slower than many similar low-income countries (notably its neighbour Kenya) to embrace cash transfers. Informants among government, donor and civil society proponents of cash transfers almost unanimously asserted that there had been a sea change in attitudes, with rapidly growing acceptance of cash transfers (particularly a social pension). DFID's assessment of progress in the ESP/SAGE programme judged that on the objective of generating increased commitment to social transfers, 'outputs substantially exceeded expectations' (DFID, 2013: 10). Stephen Kasaija said that:

'Prior to [the ESP] [political leaders and technocrats] did not know about social protection. The entire objective of this programme is to make social protection part and parcel of [general Government] plans, programmes and policies. The pilots we are doing are for generating evidence, so that you have something that is evidence-based as the basis of our [advocacy activities]. It has been very practical advocacy and we have been changing minds' (interview, Stephen Kasaija, 17 January 2014).

Promotion and lobbying efforts by both donors and the Social Protection Secretariat were clearly in evidence during fieldwork, and included a range of efforts. Among these were support for civil society advocacy by funding events and activities, including direct DFID funding for the Uganda Platform on Social Protection and the funding of consultative workshops by the Secretariat from the ESP budget. ${ }^{52}$ (A senior DFID official, however, judged civil society efforts in general quite weak. ${ }^{53}$ ) Further, the Secretariat employed a dedicated Advocacy Advisor (quoted earlier), who reported pursuing as frequent as possible engagements with senior technocrats, members of the Executive and legislators. The Secretariat had supported the establishment of a Parliamentary Forum on

\footnotetext{
${ }^{51}$ Interview, Rosemary Nyakikongoro, MP (29 January 2014).

${ }^{52}$ Interviews, Alfred Nuamanya Buhitsya (30 January 2014); David Tumwesigye (13 January 2014).

${ }^{53}$ Interview, Rachel Waterhouse (13 January 2014).
} 
Social Protection, ${ }^{54}$ formally launched in February 2014 with substantial interest from MPs and even the news media. ${ }^{55}$

Flavia Kabahenda, MP (chairperson of the Parliamentary Forum) said in response to question about support for cash transfers among technocrats, politicians and MPs:

'I'm cognisant of the fact that social protection is a new concept in the development agenda. ... But I'm glad that when it was introduced by development partners, Uganda accepted to pilot it and study whether the government can go in for it.

As the Forum on Social Protection, we have tried to look for all the government assurances on social protection, starting with the Constitution of course. Clause 16 of our Constitution specifies that the government commits itself to supporting and protecting the welfare of vulnerable persons. ... [The government has given many assurances] and it has signed protocols, including the Livingstone Call for Action. So we bank on that to say that this is not a privilege, it's a right. It's a right to which government has committed and we are demanding the implementation of that right' (interview, Flavia Kabahenda, 4 February 2014).

As mentioned earlier, the Secretariat had even made extensive efforts to influence the President himself, but had by early 2014 not succeeded in securing a direct audience with Museveni. As part of ESP activities, Ministers and MPs were even taken on several 'study tours' to countries with extensive cash transfer programmes, including South Africa, Lesotho, Brazil and Mauritius. ${ }^{56}$ These study tours were seen by social development bureaucrats as an important component of their efforts to influence political and opinion leaders.

\footnotetext{
${ }^{54}$ Interviews, David Tumwesigye (13 January 2014); Flavia Kabahenda (4 February 2014).

55 The author had the privilege of attending the launch and was struck by the enthusiasm expressed by a number of MPs for both the SAGE pilot and the national roll-out of a social pension. Senior social development bureaucrats, like Beatrice Okillan and Pius Okello, outlined both evidence of the pilot's success and the Secretariat's proposed rollout plan for a domestically-funded national social pension. No donors were present at the launch, and social development bureaucrats were clearly trying both to strengthen the coalition in support of cash transfers that they had been working to construct (and which included prominent MPs) and to pre-empt potential opposition by presenting strong evidence of the efficacy, affordability and feasibility of cash transfers.

${ }^{56}$ Delegations including Ministers, technocrats and Members of Parliament visited Lesotho and South Africa in November 2011, Brazil in March 2012 and Mauritius during February 2014.
} 
After 2010, social development bureaucrats were clearly the primary advocates of expanded social protection, and the donors' role had become one primarily of supporting these bureaucrats. With respect to agenda-setting and political support-building, it seems reasonable to refer to the period from the start of SAGE's implementation as the era of bureaucratic advocacy on cash transfers.

\section{Conclusion}

Explaining growing acceptance of cash transfers in Uganda is difficult, and this paper does not fully do so. The broader issues and other factors-including that prevailing political discourse have changed over the period-are treated in greater detail in Grebe and Mubiru (2014). This paper contributes to the existing literature on welfare policy reform in Uganda-which recognises the critical importance of domestic politics - by highlighting the process by which donors and, more specifically, social development bureaucrats helped shape the domestic political agenda over the period 2002-2013.

The paper has presented evidence that social development bureaucrats enthusiastically embraced an originally primarily donor-driven agenda of promoting cash transfers. It also showed how donors had to modify both their policy preferences and strategy for promoting policy reform in response to domestic political realities and increasingly retreated into the background as bureaucrats became the front-line advocates.

Before donors threw their considerable financial weight and influence behind them, social development bureaucrats had little influence over the rest of the bureaucracy (especially financial technocrats) or the broader political agenda. But with donor support, these bureaucrats managed to embed social protection and social assistance in general, cash transfers in particular (and especially social pensions) firmly in the domestic political agenda. Donor investment in these bureaucrats' capacity reflected a realisation that their own efforts at securing domestic political support had largely failed. With support from civil society and a section of the political elite (particularly MPs who see electoral advantages), these bureaucrats had secured a pilot cash transfer and significantly contributed to the emergence of a strong coalition in support of a national social pension. Their role was not only important but essential to the approval and success of the SAGE pilot. Herein lies the paper's central contribution: previous studies have not given sufficient recognition of the donor-bureaucrat alliance at the heart of promoting welfare policy reform in Uganda.

Explaining why historically weak social development bureaucrats (and given that the literature suggests bureaucrats in general were subject to executive 
domination) had sufficient influence and power to, with the assistance of donors and to some extent civil society, alter the Ugandan development policy agenda requires careful consideration of the specific political conditions within which it occurred. Insufficient data is available to render final judgement on this, but the evidence presented here suggests that the following factors may help explain the paradox: (1) ideas matter, and convincing political leaders and some financial technocrats made a real difference; (2) closely related to the first point-explicit and deliberate advocacy efforts - which were aimed broadly, met with success in part because of sheer persistence and in part because certain kinds of (carefully chosen) arguments resonated sufficiently within policy and political elites (such as presentation of cash transfers as 'developmental'); (3) consultative policy-making processes allowed bureaucrats, donors and civil society to ensure social protection 'language' entered formal planning and policy documents in ways that helped generate and sustain the momentum of agenda-setting and advocacy; and (4) perceived electoral advantages and the dynamics of 'competitive clientelism' (Golooba and Hickey, 2013) may have created incentives on politicians in the Executive and Legislature to support cash transfers. It may also be that weak opposition parties, a weak legislature and executive dominance actually free bureaucrats from effective political oversight, adding to their power to influence the policy agenda. These and other factors are addressed more fully in Grebe and Mubiru (2014).

Despite this substantial progress in winning support for, building capacity to implement, and planning for a national social pension, the future of cash transfers in Uganda remained uncertain by early 2014. In spite of encouraging signs, the limits to donor and bureaucratic power in Uganda were also clear from the research. Presidential support remained open to doubt, questions over the scalability of the existing implementation model had not been settled and resistance from fiscally conservative technocrats and some politicians to financing a national programme may well still have been insurmountable. The tremendous optimism among many social development bureaucrats, donor officials and members of parliament therefore seemed premature.

\section{Postscript: A turning point in political support for a national social pension?}

By the end of 2013, a national social pension was firmly on the national agenda, ${ }^{57}$ the major parties had endorsed it (already for the 2011 election), it was

\footnotetext{
${ }^{57}$ It would probably be inaccurate to say that cash transfers in general had become widely accepted-it was specifically a social pension that was gaining acceptance and only the SCG that was being considered for national rollout. The VFG was strikingly absent from
} 
being debated in Parliament, in publicly in newspapers, and the informants interviewed for this research were almost unanimous in their optimism that a national social pension would be implemented. This was evident at the public launch of the Parliamentary Platform on Social Protection in February 2014.

Substantial capacity had been created within the MGLSD to implement cash transfers. Systems had been put in place that allowed the national-level Social Protection Secretariat to deploy staff and systems to the regional and local levels for day-to-day implementation. Significant investments were made by the payments service provider and most teething problems had been ironed out. ${ }^{58}$ But it remained to be seen how robust this capacity would prove once the technical assistance delivered as part of the donor support came to an end (or declined in significance) if the programme were scaled up significantly. Furthermore, the scalability of systems and practices were in question: in order to support implementation of the pilot, substantial resources had been deployed from the centre, and districts and counties had received considerable assistance (for example, with filling relevant local vacancies and training of local-level officials). Recruiting sufficient and appropriately qualified staff had been identified as a challenge in the pilot, raising the question as to whether this practice could be sustained at national scale.

The research reported here reveals that cash transfers were by early 2014 increasingly being presented by proponents as not merely a poverty alleviation mechanism but as a way to stimulate local economic development, aggregate demand (i.e. positively impact the macroeconomy) and entrepreneurial activity. ${ }^{59}$ There appeared to be a growing acceptance that certain sections of the population were unlikely to benefit much (at least in the short to medium term) from economic development. The phrase 'inclusive development' was in wide use, with cash transfers seen as one way to ensure that the most marginalised (including, and most especially the aged) were not left entirely out of the

discussions of the SAGE pilot, even by the officials responsible for its implementation. The three most probable reasons for this (based on a broad view of informant responses) were (1) the difficulties associated with its implementation, most notably the onerous data collection requirements of its vulnerability targeting; (2) the controversy it sometimes gave rise to at community level (several informants, including Pius Okello, interview, 5 February 2014; and Beatrice Okillan, interview, 13 January 2014, indicated that its complex vulnerability ranking methodology was poorly understood by beneficiary communities, resulting in disputes over eligibility and allegations of favouritism); and (3) the greater political acceptability of direct income support to older persons than poverty-targeted cash transfers.

${ }^{58}$ Interview, Pius Okello (5 February 2014).

59 This argument is increasingly common among proponents of cash transfers globally. See, for example, Hanlon et al. (2010) and Barrientos (2013). It was also prominent in Beatrice Okillan's presentation to Members of Parliament during the launch of the Parliamentary Forum (Okillan, 2014) 
development process. ${ }^{60}$ These may have reflected both an increasingly receptive political environment and carefully-tailored messages designed to resonate with specific audiences.

Furthermore, public demand and the perceived electoral advantages of supporting the pilot and its expansion were widely cited by respondents as a reason for optimism. The SAGE pilot was widely seen as an extremely popular programme that had greatly enhanced the visibility of the government in the remote and rural communities where many beneficiaries lived. Many informants attributed the growing political support for the pilot - especially in Parliamentto politicians noticing its popularity and potential as a vote-winner. Some MPs argued that it would be 'political suicide' to oppose the programme. In fact, both the NRM and the Forum for Democratic Change (the official opposition) included a commitment to social pensions in their election manifestos for the 2011 election, with the latter even including the specific commitment of doubling the size of the monthly payment. ${ }^{61}$

In August 2013, the President wrote to the Minister of Gender, Labour and Social Development, instructing her to develop a national rollout plan in collaboration with the Finance Ministry and to publish it publicly. This directive from the President was interpreted by social development bureaucrats as a strong indication of presidential support (which in turn was considered a prerequisite for national rollout), and had greatly encouraged ESP officials who felt unsure of the success of their efforts at lobbying Museveni. Also interpreted as an encouraging sign was the direct presidential instruction to add a fifteenth district to the pilot, referred to earlier. This instruction reportedly followed a request from senior NRM figures in the Yumbe district, which necessarily also raises questions about the use of the pilot as a means of deploying patronage, and in particular what role patronage may play in a national rollout with more limited donor involvement.

A large majority of informants were very confident that the national rollout of a social pension would go ahead. As Barrett pointed out, 'the Government has committed funds now-when they did this, they knew there was no turning back. ${ }^{62}$ Flavia Kabahenda, MP (chairperson of the Parliamentary Forum) was optimistic:

\footnotetext{
${ }^{60}$ Interview, Nahalamba Sarah Birungi (20 January 2014).

61 The NRM's election manifesto states that "The NRM Government will roll out the cash transfer program for older persons" (NRM, 2010:41) and the FDC's that it "will pay UGX 50,000 per month to persons over 65 years" (FDC, 2010: 20).

${ }^{62}$ Interview, Stephen Barrett (6 February 2014).
} 
'The government has appreciated that the impact of the pilot is very positive. They really appreciate the fact that it has improved the livelihoods of [beneficiaries], improved the quality and quantity of meals [consumed], the health and even supporting orphaned children to attend schools. And that gives me optimism that when we talk about rollout, I think government will buy it very very well' (interview, Flavia Kabahenda, 4 February 2014).

A number of uncertainties nevertheless remained. While a national rollout plan had been drafted by early 2014, which officials were confident was affordable, ${ }^{63}$ a decision was not expected be made quickly. Politicians may find it hard to agree on a phased rollout plan. ${ }^{64}$ While the selection of fourteen (now fifteen) districts could be accepted while the programme was in pilot phase and largely funded by donors, disagreements over the details of any plan to slowly add districts to the programme were expected. For this reason the MGLSD's rollout plan proposed a relatively quick four-year phase-in and presented both "full district" and "partial district" options - in the latter, a selection of sub-counties within all districts would be included from the first year (Okillan, 2014) probably with a view to securing wide parliamentary support, since all MPs' constituencies would start benefitting early. Stephen Barrett expressed the fear that approval would be stalled by these potential disagreements or that a tooquick rollout (that overwhelms the capacity of implementing institutions) would be agreed.

Several respondents expected that any announcement would be made at the most politically opportune time with a view to the 2016 election. Only time will tell whether 2013/2014 will in fact turn out to be the turning point in support for a national social pension that it appeared to be at the time.

63 The Social Protection Secretariat had by mid-2013 started the process of exploring financing options and costing the scale-up of the cash transfer pilot through an exercise known as the Uganda Social Protection Financing Options Study (see Cammack and Twinamatsiko, 2013). The Secretariat estimated the costs of scaling up the Senior Citizens Grant nationally over a five year period and claimed that the scale-up could be financed entirely out of a 'small portion of projected revenue growth' (Okillan, 2014).

${ }^{64}$ Interview, Stephen Barrett (6 February 2014). 


\section{References}

ADB et al. 2005. Joint Assistance Strategy for the Republic of Uganda. African Development Bank, Austria, Germany, The Netherlands, Norway, Sweden, UK Department for International Development and The World Bank. Available at: http://siteresources.worldbank.org/INTUGANDA/Resources/UJAS.pdf

Barrientos, A. 2013. Social Assistance in Developing Countries. Cambridge: Cambridge University Press.

Bitaliwo, O. 2014. 'Bureaucracy: The Case of Uganda' in International Journal of Public Administration and Management Research, 2(3), pp. 39-49.

Bukuluki, P. \& C. Watson. 2012. Transforming Cash Transfers: Beneficiary and community perspectives on the Senior Citizen Grant (SCG) in Uganda. London: Overseas Development Institute.

Byaruhanga, J. 2013. State, Bureaucracy and Government: Uganda's Challenge and Possible Solutions. Unpublished M.A. thesis, University of Osnabrück.

Cammack, T. \& F. Twinamatsiko. 2013. Uganda Social Protection Financing Options Study: Final Report. Kampala: Expanding Social Protection Programme, Ministry of Gender, Labour and Social Development.

CPRC Uganda. 2005. Chronic Poverty in Uganda: The Policy Challenges. Kampala: Chronic Poverty Research Centre Uganda. Available at: http://www.chronicpoverty.org/publications/details/chronic-poverty-in-ugandathe-policy-challenges/ss

Deininger, K. 2003. Does cost of schooling affect enrolment by the poor? Universal primary education in Uganda. Economics of Education Review 22(3): 291-305. doi:10.1016/s0272-7757(02)00053-5

Devereux, S., Ntale, C.L. \& R. Sabates-Wheeler. 2002. Social Protection in Uganda: Study to Inform the Development of a Framework for Social Protection in the Context of the Poverty Eradication Action Plan (Phase I Report: Vulnerability Assessment \& Review of Initiatives. Kampala: Social Protection Task Force.

DFID. 2013. Annual Review: Expanding Social Protection in Uganda. London: Department for International Development, 4 November. 
ESP. 2013. Expanding Social Protection. Website. Kampala: Expanding Social Protection Programme, Ministry of Gender, Labour and Social Development. Available at: http://www.socialprotection.go.ug

ESP. undated. Poverty, Vulnerability, and Inequality in Uganda. Kampala: Expanding Social Protection Programme, Ministry of Gender, Labour and Social Development. Available at:

http://www.socialprotection.go.ug/pdf/Policy\%20publications/Poverty,\%20Vuln erability\%20and\%20Inequality\%20in\%20Uganda.pdf

FDC. 2010. Manifesto 2011-2016. Kampala: Forum for Democratic Change.

Ferguson, J. 2012. What Comes after the Social? Historicizing the Future of Social Assistance and Identity Registration in Africa. In K. Breckenridge \& S. Szreter (eds.) Registration and Recognition: Documenting the Person in World History. Oxford: Oxford University Press.

Golooba-Mutebi, F. \& S. Hickey. 2010. Governing Chronic Poverty under Inclusive Liberalism: The Case of the Northern Uganda Social Action Fund. Journal of Development Studies, 46(7): 1216-1239.

Golooba-Mutebi, F. \& S. Hickey. 2013. Investigating the links between political settlements and inclusive development in Uganda: towards a research agenda. ESID Working Paper No. 20. Manchester: Effective States and Inclusive Development Research Centre, University of Manchester.

GoU (Government of Uganda). 2010. National Development Plan (2010/11 2014/15). Kampala: Government of Uganda.

GoU. 2013. Uganda Vision 2040. Kampala: Government of Uganda.

Grant, U. 2006. Research into policy processes: Bringing global evidence on social protection into local policy contexts [Background Paper for the Chronic Povery Report 2008-09]. Manchester: Chronic Poverty Research Centre.

Grebe, E. \& J.B. Mubiru. 2014. Social policy reform in Uganda under the NRM and Museveni: How and why has social policy increasingly embraced cash transfers? CSSR Working Paper No. 353. Cape Town: Centre for Social Science Research, University of Cape Town. Available at: http://cssr.uct.ac.za/pub/wp/353/

Hanlon, J., Barrientos, A. \& D. Hulme. 2012. Just Give Money to the Poor: The Development Revolution from the Global South. Sterling, VA: Kumarian Press. 
HelpAge International. 2006. Social cash transfers for Africa: A transformative agenda for the 21 st century. Intergovernmental regional conference report, Livingstone, Zambia, 20-23 March 2006. London: HelpAge International. Available at: http://www.ipcundp.org/publications/cct/africa/CashTransfersAfrica.pdf.

Hickey, S. 2003. The Politics of Staying Poor in Uganda. CPRC Working Paper No. 37. Manchester: Chronic Poverty Research Centre.

Hickey, S. 2012. 'Beyond the Poverty Agenda? Insights from the New Politics of Development in Uganda.' World Development, 43: 194-206.

Hickey, S., Sabates-Wheeler, R., Guenther, B. \& I. Macauslan. 2009. Promoting Social Transfers: DFID and the Politics of Influencing. DFID Working Paper 32. London: Department for International Development.

Izama, A. \& M. Wilkerson. 2011. Uganda: Museveni's Triumph and Weakness. Journal of Democracy, 22(3): 64-78.

Kabandula, A. \& J. Seekings. forthcoming. Donor influence, the Minister of Finance and welfare policy reform in Zambia, 2003-11. CSSR Working Paper. Cape Town: Centre for Social Science Research, University of Cape Town.

Kasaija, S. 2011. Senior Citizens Grants \& Vulnerable Family Grants. Powerpoint Presentation. Available at: http://www.socialprotection.go.ug/

Mamdani, M. 1976. Politics and Class Formation in Uganda. Kampala: Fountain Publishers.

Melo, M.A., Ng'ethe, N. \& J. Manor. 2012. Against the Odds: Politicians, Institutions and the Struggle Against Poverty. London: Hurst \& Company.

MFPED. 1997. Poverty Eradication Action Plan. Kampala: Ministry of Finance, Planning and Economic Development.

MFPED. 2004. Poverty Eradication Action Plan (2 $2^{\text {nd }}$ Revision). Kampala: Ministry of Finance, Planning and Economic Development.

MFPED. 2012. Poverty Status Report: Poverty Reduction and the National Development Process. Kampala: Economic Development Policy and Research Department, Ministry of Finance, Planning and Economic Development. Available at: http://www.opendev.ug/sites/opendataug01.drupal01.mountbatten.ug/files/poverty_status_report_2012.pdf 
MGLSD. 2003. The Social Development Sector Strategic Investment Plan (SDIP). Kampala: Ministry of Gender, Labour and Social Development.

MGLSD. 2007. Design of a Cash Transfer Pilot for Uganda. Kampala: The Uganda Social Protection Task Force, Ministry of Gender, Labour and Social Development.

MGLSD. 2011. The Social Development Sector Strategic Investment Plan (SDIP 2): 2011/12 -2015/16. Kampala: Ministry of Gender, Labour and Social Development.

Mosley, P. 2012. The politics of poverty reduction. Oxford: Oxford University Press.

Mugambe, K. 2011. The Poverty Eradication Action Plan. In Kuteesa, F., Tumusiime-Mutebile, E., Whitworth, A. \& T. Williamson (eds.) Uganda's Economic Reforms: Insider Accounts. Oxford: Oxford University Press, pp. 157171.

Mwenda, A.M. 2007. Personalizing Power in Uganda. Journal of Democracy, 18(3): 23-37.

Nambyonga, J., Desmet, M., Karamagi, H., Kadama, P.Y., Omaswa, F.G. \& O. Walker. 2005. Abolition of cost-sharing is pro-poor: evidence from Uganda. Health Policy and Planning, 20(2): 100-108.

Nishimura, M., Yamano, T. \& Y. Sasaoka. 2008. Impacts of the universal primary education policy on educational attainment and private costs in rural Uganda. International Journal of Educational Development, 28(2): 161-175.

NRM. 2010. Manifesto 2011-2016. Kampala: National Resistance Movement.

Okillan, B. 2014. Supporting older people and their families to contribute to and benefit from Uganda's social and economic transformation: Updates, Status \& Rollout of the SAGE Senior Citizen Grant scheme. Presentation by Beatrice Okillan (Policy \& Learning Manager, Expanding Social Protection Programme, Ministry of Gender, Labour \& Social Development) at launch of Parliamentary Forum on Social Protection. Kampala: Uganda, 4 February.

OPM. 2010. Northern Uganda Social Action Fund II (NUSAF II).Kampala: Office of the Prime Minister. Available at: http://opm.go.ug/projects/northernuganda-social-action-fund-ii-nusaf-iil.html [Retrieved 2 November 2014]. 
Orem, J.N., Mugisha, F., Kirunga, C. Macq, J. \& B. Criel. 2011. Abolition of user fees: the Uganda paradox. Health Policy and Planning, 26(suppl. 2): ii41ii51.

Reinikka, R. 2001. Recovery in Service Delivery: Evidence from Schools and Health Centers. In Reinikka, R. \& P. Collier (eds.) Uganda's Recovery: The Role of Farms, Firms and Government. Washington, DC: World Bank, pp. 343370.

Reinikka, R. \& J. Svensson. 2011. The power of information in public services: Evidence from education in Uganda. Journal of Public Economics, 95(7-8): 956-966.

Robichaud, V., Tiberti, L. \& H. Maisonnave. 2014. Impact of increased public education spending on growth and poverty in Uganda. An integrated micromacro approach. PEP-MPIA Working Paper 2014-01. Québec: PEP-MPIA. Available at: http://ideas.repec.org/p/lvl/mpiacr/2014-01.html

Seekings, J. 2013. The Politics of Social Policy in Africa. In Cheeseman, N., Anderson, D. \& A. Scheibler (eds.) Routledge Handbook of African Politics. London: Routledge, pp. 309-321.

Tripp, A.M. 2010. Museveni's Uganda: Paradoxes of Power in a Hybrid Regime. Boulder, CO: Lynne Rienner.

World Bank. 2014. World Bank Open Data. Available at: http://data.worldbank.org 